\title{
Investigation of Nitrate Pollution in Groundwater Used for Irrigation in Konya-Karapinar Region, Central Anatolia
}

\author{
Gökhan BÜYÜK ${ }^{1 *}$, Erhan AKÇA ${ }^{2}$, Takashi KUME ${ }^{3}$, Takanori NAGANO ${ }^{4}$ \\ ${ }^{1} \mathrm{AU}$, Kahta Vocational School, Kahta, Adiyaman, Turkey \\ ${ }^{2}$ AU, Technical Programs, Adiyaman, Turkey \\ ${ }^{3} \mathrm{EU}$, Department of Rural Engineering, Japan \\ ${ }^{4}$ KU, Graduate School of Agricultural Science, Dept. of Agricultural Engineering and Socio-Economics, Japan
}

Received (Geliş): 21.01.2016

Accepted (Kabul): 09.04.2016

\begin{abstract}
Groundwater nitrate pollution risks via excess agrochemical use are a serious problem for human health, livestock and environment both in Turkey and the world. This is a particularly serious threat in areas where irrigation is undertaken by groundwater as in the closed basin of Konya in Central Turkey. The $70 \%$ of groundwater irrigation wells in Konya run privately or by state institutions contain NO3-N level of greater than $10 \mathrm{mg} / \mathrm{L}$. The remaining wells' nitrate content varied from $3 \mathrm{mg} / \mathrm{L}$ to $10 \mathrm{~g} / \mathrm{L}$, which all indicate an anthropogenic pollution although the levels of $\mathrm{N}$ is still not harmful for crop production. Moreover, about $\% 20$ wells $\mathrm{EC}$ is greater than the recommended levels for livestock $(\mathrm{EC}>1000 \mathrm{mg} / \mathrm{L})$. Thus, the nitrate level of groundwater wells used for irrigation is within the permissible (tolarable) level for agricultural uses. However, the consumption by humans and animals is not recommended, because the irrigation in Konya Closed basin, extends to almost $5 \mathrm{M}$ ha, is undertaken by 100.000 groundwater wells and out of $60 \%$ are illegally operated. This study was conducted from 2009 and 2012 in Karapınar region of the Konya Basin, which is intensively irrigated with ground water. The average $\mathrm{NO}_{3}-\mathrm{N}$ level of groundwater wells was $11.7 \mathrm{mg} / \mathrm{L}$ due to excess irrigation from May to August. During irrigation season $83.4 \mathrm{~kg}$ $\mathrm{NO}_{3}$-N.ha ${ }^{-1}$ was unconsciously applied to fields with irrigation. The high fertilizer use and excess irrigation by groundwater wells in the region necessitate precise calculation of nitrate which is contributed from groundwater wells. Thus, chemical nitrogen use will be optimized for preventing pollution of water resources particularly in sugar beet and second crop maize production as irrigation is undertaken 10 to 12 times and 12 to 15 hours. Otherwise, in near future the environment and human health will face serious consequences.
\end{abstract}

Key Words: Nitrate, Groundwater, Pollution, Konya closed basin.

\section{Konya-Karapınar Bölgesinde, İç Anadolu, Sulama için Kullanılan Yeraltı Sularında Nitrat Kirliliğinin Araştırılması}

ÖZET: Yeraltı sularında nitrat kirliliği riski aşırı azot gübrelerinin kullanımıyla insan sağlığı, çevre ve çiftlik hayvanları için Türkiye hem de Dünya'da ciddi bir problemdir. Bu durum, özellikle Türkiye'de Konya gibi kapalı havzalarda yeraltı suları ile yapılan sulama alanlarında ciddi bir tehdittir. Konya'daki kamu veya özel kişiler tarafından tarımsal amaçlı sulamalar için açılmış yeraltı su kuyularının \% 70'inde $\mathrm{NO}_{3}-\mathrm{N}$ dzüeyi $10 \mathrm{mg} / \mathrm{L}$ 'nin üzerindedir. Geriye kalan kuyuların N içeriği 3-10 mg /L arasında değişmektedir ki tarımsal üretim için zararlı düzey olmamasına karşın bu insan etkisini ortaya koymaktadır. Ayrıca, su kuyularının \% 20'sinde EC konsantrasyonu tavsiye edilen seviyenin olan EC $>1000 \mathrm{mg} / \mathrm{L}$ üzerindedir. Bu nedenle, sulama amaçlı kullanılan yeraltı kuyularında nitrat seviyesitarımsal kullanım için izin verilen değerler içinde iken insanlar ve hayvanlar tarafından kullanımı önerilmemektedir çünkü Konya Kapalı Havzasında neredeyse 5 milyon ha'a ulaşan sulama, \%60’1 resmi izin alınmadan işletilen 100.000 yeraltı kuyusundan gerçekleş̧irilmektedir. Bu çalışma, 2009 ile 2012 yıllarında Konya havzasında sulamanın yoğun olarak yeraltı kuyularıyla yapıldığı Karapınar Bölgesine gerçekleştirilmiştir. Mayıs-Ağustos döneminde aşırı sulamadan dolayı yeraltı kuyu sularında ortalama $\mathrm{NO}_{3}-\mathrm{N}$ düzeyi $11.7 \mathrm{mg} / \mathrm{L}$ 'dir.Sulama dönemindeki $83.4 \mathrm{~kg} \quad \mathrm{NO}_{3}-\mathrm{N} \cdot \mathrm{ha}^{-1}$ bilinçsizce sulama ile tarım alanlarına uygulanmaktadır. Yüksek azotlu gübre uygulaması ve nitratça zengin yeraltı sularıyla yapılan aşırı sulamadan dolayı yeraltı kuyularından gelen nitrat hesabı dikkatli yapılmalıdır. Bu yüzden, su kaynaklarının kirliliğini önlemek için kimyasal azot kullanımı özellikle şeker pancarı ve mısır tarımının yoğun olduğu bu bölgede sulama $10-12$ kez ve her sulama 12-15 saat süreyle kuyu sularından yapıldığından optimize edilmelidir. Aksi durumda yakın gelecekte çevre ve insan sağlı̆̆ sorun yaşayabilecektir.

Anahtar Kelimeler: Nitrat, Yeraltı suyu, Kirlilik, Konya kapalı havza

\section{INTRODUCTION}

The nitrogen fertilizer use in Turkey exceeds $11.5 \mathrm{M}$ tons $(21 \% \mathrm{~N})$ as of 2011 , and in Konya, the largest agricultural basin of Turkey with 500.000 ha (TÜiK, 2012). Although Turkey is quite rich with its river catchment basins such as Euphrates and Tigris, the natural river network in Konya Basin lags behind to meet irrigation demand, thus majority of the irrigation is provided from groundwater wells totaling to 100.000 (KOP, 2012). 
Moreover, groundwater is also the main source for domestic water demands of Konya city. Approximately $75 \%$ of the city's water consumption has been supplied from 250 groundwater wells since 2000s (Buldur, 2010). One of the important quality parameter of domestic water is the nitrate content. Nas and Berktay (2006) determined nitrate levels of groundwater in city center varying from 2.2 and $16.1 \mathrm{mg} / \mathrm{L}$ for the years of 1998 and 2001 which were below permissible level of $50 \mathrm{mg} / \mathrm{L}$ for $\mathrm{NO}_{3}$. The permissible nitrate nitrogen $\left(\mathrm{NO}_{3}-\mathrm{N}\right)$ level by Turkish Standards Institute (TSE, 1997) is $10 \mathrm{mgL}^{-1} \mathrm{NO}_{3}$ - . The nitrate regulation in Turkey is quite strict as nitrates are known to have health impacts if consumed in excess concentrations. These include methemoglobinemia in infants, gastric lymphoma in adults, miscarriages among pregnant women, insulin-dependent diabetes mellitus, thyroid disease and increased risk for Non-Hodgkin Lymphoma (Khazenzi et. al. 2013).

The high nitrogen demanding crop pattern in Karapınar region such as maize, potatoes, sugar beet caused excess use of nitrogen bearing fertilizers (Rosenstock et. al., 2013). Agricultural activities are the major non-point sources of nitrate contamination of groundwater because of greater use of nitrogen fertilizer on crops (Kuzelka and Ennenga, 2013).

$\mathrm{NO}_{3}-\mathrm{N}$ contamination costs an environmental health risk because many rural areas obtain drinking water from wells that are often shallow and vulnerable to contamination (Guillette and Edwards 2005; Harter and Lund, 2012). Gao et. al., (2012) monitored water quality changes in 29 wells in China between 2009 and 2010 And determined high nitrate contents in $90 \%$ of the monitored wells which was considered as cancerogenic threat based on Chinese Health Risk Assessment.

Huang et.al. (2010) reported that agricultural activities near wells is the main factor in groundwater's high nitrate content. Excess irrigation and overuse of fertilizers are argued as the main reasons for multiplying groundwater's nitrate concentration (Jackson et. al. 2008). The increase in chemical fertilizer use, wastes and groundwater irrigation are suggested as main driving forces leading increased groundwater nitrate concentration since 1990s in Konya region. Thus, the nitrate concentration easily reaches couple of hundred $\mathrm{mg} / \mathrm{L}$ in groundwater due to agricultural activities based on excess use of agro-chemicals in the region (Yilmaz et al., 2010).

In Konya, the main source of drinking water is groundwater aquifer, therefore excessive nitrate concentrations in groundwater inarguably a health hazard for the locals. Thus, (1) the distribution of nitrate concentration in groundwater wells and (2) the dimension of nitrate pollution in Karapınar region were studied from 2009 and 2012 for informing locals on contamination which may be harmful both people and environment sometime soon.

\section{MATERIAL and METHODS}

\section{Study area}

The study is undertaken from 2009 to 2012 in a $4000 \mathrm{~km}^{2}$ area extended mainly in Karapınar town and on the borders of Ereğli and Karaman towns. Study area is located in closed Great Konya Basin, and extensively irrigated from groundwater wells. Also for baseline information, surface water samples were collected from Tuz (Salt) Lake in the northern edge and from İvriz River Taurids in the southern edge of the study site originated from extends the study site $170 \mathrm{~km}$ from North to South and $150 \mathrm{~km}$ East to West (Figure 1). The region has a semi-arid climate with an average $300 \mathrm{~mm}$ annual precipitation along with more than $1600 \mathrm{~mm}$ evaporation.

\section{Sampling}

Water samples were collected from 19 groundwater wells and surface waters that spread in the study site that all presented various land uses during irrigation period of May and August two times a year from 2009 to 2012

Water samples were taken by using $0.02 \mu \mathrm{m}$ diameter membrane filters for avoiding organic contamination by microorganisms during storage and preparation to analysis (Kume et. al., 2010). The fertilizers used predominantly in Central Anatolia (urea, ammonium sulfate and $\mathrm{N}: \mathrm{P}: \mathrm{K}$ ) were obtained as endcomponents salts for analysis.

\section{Chemical analysis}

Water samples were filtered through a $0.2 \mu \mathrm{m}$ cellulose-acetate filter before determining the nitrate. Samples were placed in cooled containers and kept at $4^{\circ} \mathrm{C}$ until preparation for analysis. The nitrate content of samples, was determined according to sodium-salicylate method (Schlichting ve Blume, 1966). The reference solutions nitrate concentrations were 0.1 and $10 \mathrm{mg} \cdot \mathrm{l}^{-1}$. The spectrophotometric readings were undertaken at $410 \mathrm{~nm}$ wavelength. Samples were analyzed in Research Institute of Humanity and Nature, Kyoto (Japan). Electrical conductivity (EC) and $\mathrm{pH}$ were determined according to Richards (1954).

ICP-MS Agilent 7500cx was employed for the heavy metals analysis in Research Institute of Humanity and Nature, Kyoto (Japan). Standards, a total of 6 were prepared from $1.000 \mathrm{mg} / \mathrm{L}$ ranged from $0.001 \mathrm{mg} / \mathrm{L}$ to $0,1 \mathrm{mg} / \mathrm{L}$. various concentrations of the standards were tested and a reference linear curve was prepared. 


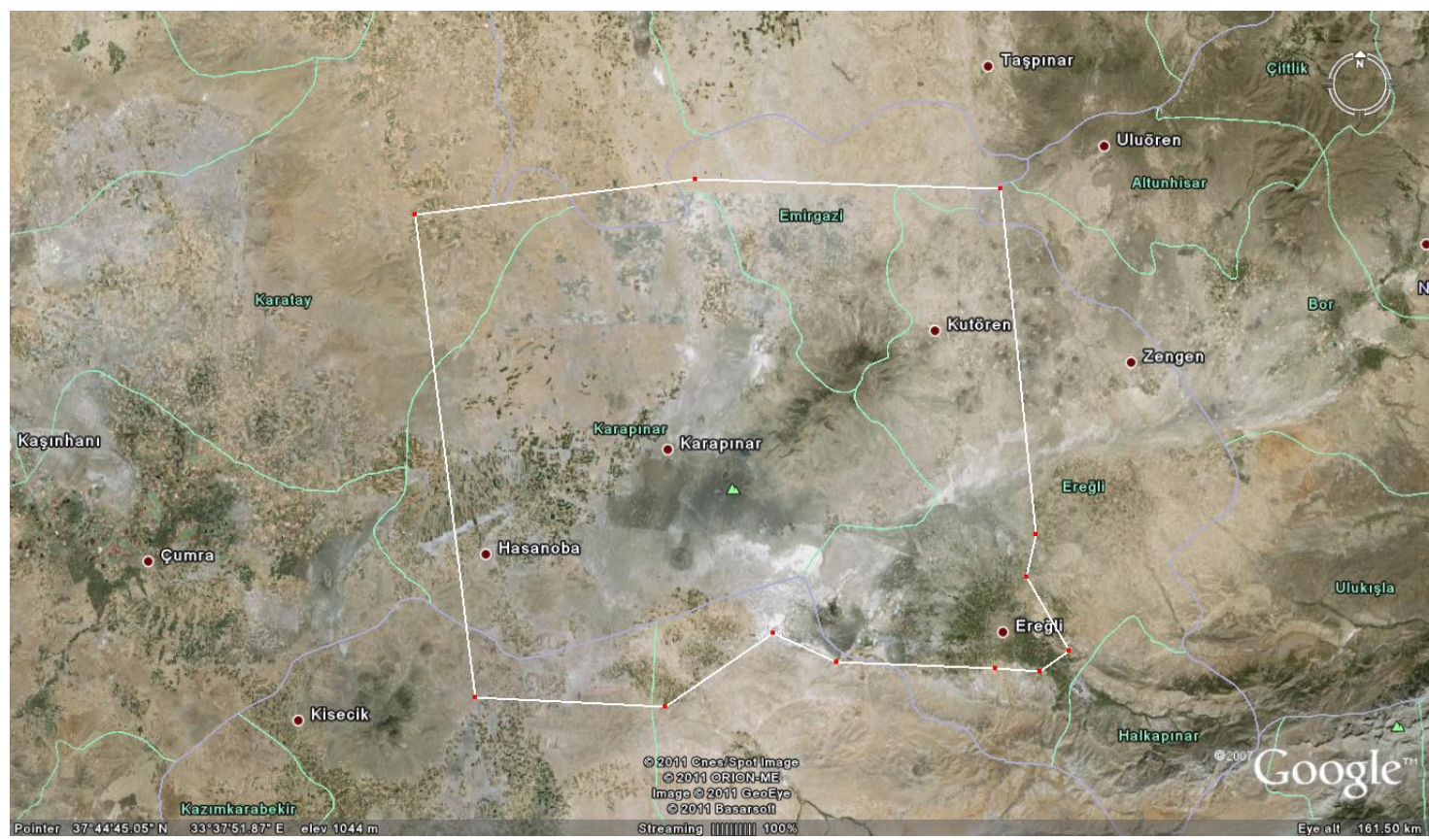

Figure 1. Study area

\section{RESULTS and DISCUSSION}

\section{Assessments of Electrical Conductivity}

Besides an alkaline $\mathrm{pH}$ groundwater distribution in study area, the waters of Erosion Control Station on the western edge of city center and ancient lake on northern edge of Karapınar town has high EC $(0.25-0.75 \mathrm{dS} / \mathrm{m})$ (Table 1) (Richards, 1954) than the rest of the region. This high EC may manifest the high probability of salt layer in other groundwater wells below organic deposition layers of ancient inner lake in Karapinar
(Lapwort et. al., 2012; Üstün et.al. 2015). Moreover as Konya Plain is a closed basin, the infiltrated water reaches groundwater which also revealed a pollution cycle of natural water resources (Varol et. al., 2012).

While $35 \%$ of the groundwater wells used both for irrigation and drinking purposes has medium (0.25-0.75 $\mathrm{dS} / \mathrm{m}) \mathrm{EC}$ rates, the $35 \%$ of the sample site has no salinity and the remaining $30 \%$ has low EC $(<0.25$ dS/m)(Table 1) (Richards, 1954).

Table 1. Location, $\mathrm{pH}$ and Electrical conductivity (EC) of water samples

\begin{tabular}{cccclccc}
\hline Well No & West & North & Latitude & \multicolumn{1}{c}{ Location } & Depth $(\mathrm{m})$ & $\mathrm{pH}$ & $\mathrm{EC}(\mathrm{dS} / \mathrm{m})$ \\
\hline 1 & 571507 & 4166013 & 1096 & DSI-52 pump & 60 & 7.4 & 0.92 \\
2 & 603811 & 4140919 & 1167 & İvriz & Surface & 7.8 & 0.14 \\
3 & 594248 & 4160109 & 1035 & Ereğli & 25 & 8.7 & 0.79 \\
4 & 568217 & 4165754 & 1033 & Kazanhöyüğ̈ & 40 & 7.4 & 0.99 \\
5 & 558348 & 4173884 & 1057 & Acıgöl & Surface & 7.9 & $>20$ \\
6 & 559589 & 4179159 & 1007 & MenikYaylas1 & 80 & 7.2 & 4.3 \\
7 & 550045 & 4163992 & 1004 & Vahapohasi & 14 & 7.8 & 10 \\
8 & 546956 & 4174132 & 1011 & Karapınar & 60 & 6.9 & 1.88 \\
9 & 555681 & 4206529 & 1031 & ŞirakYaylas1 & 70 & 7.1 & 1.44 \\
10 & 553407 & 4210104 & 1017 & Besci & 60 & 7.5 & 1.46 \\
11 & 563858 & 4196758 & 1020 & Kurtburun & 35 & 7.5 & 0.55 \\
12 & 563741 & 4187777 & 987 & Kayalı & 25 & 6.9 & 0.52 \\
13 & 563264 & 4187589 & 986 & Kayalı & 25 & 7.1 & 0.66 \\
14 & 542724 & 4146443 & 1007 & Akçaşehir & 70 & 8.2 & 0.81 \\
15 & 529082 & 4157294 & 1003 & İslik & 55 & 6.9 & 0.61 \\
16 & 529424 & 4166757 & 1001 & Hotamış & 60 & 7.3 & 0.49 \\
17 & 542570 & 4169195 & 1001 & Erozyon Kontrol & 130 & 7.4 & 0.36 \\
18 & 551425 & 4157428 & 992 & Akyayla & 60 & 7.6 & 3.0 \\
19 & 555731 & 4148221 & 1022 & Ambarlı & 130 & 7.8 & 0.27 \\
\hline
\end{tabular}

The groundwater wells in the Konya Closed Basin highly affected from soluble and mobile materials such as gypsum, and calcium carbonate along with agrochemical that are excessively used in cultivated lands. 
Thus excess agrochemical use in the study site is negatively affecting soil and water quality. The crop pattern is dominated by maize, sugar beet, wheat and alfalfa in Konya Basin and when the groundwater wells EC exceed moderate level $(0.25-0.75 \mathrm{dS} / \mathrm{m})$, the crop yield will decrease at least 10\% (Bauder et. al., 2011).

The livestock sector is developing in Konya basin which demand high fodder which is met by alfalfa and silage maize production. These crops need high water inputs which are mainly supplied from groundwater wells. However, $20 \%$ of the wells in the region have high EC levels $(0.75-2.25 \mathrm{dS} / \mathrm{m})$ for animal husbandry which may cause serious threats to livestock production (Lapworth et. al., 2012).

\section{Health risk and nitrate assessment}

Fortunately, no heavy metal or hazardous organism pollution in any groundwater well (Table 2) was determined due to lack of industrial pollution and sparse human population in the region. Nitrate may occur naturally in groundwater, however concentrations greater than $3 \mathrm{mg} / \mathrm{L}$ generally indicate contamination (Lockhart et. al., 2013), and a more recent study suggested that concentrations over $1.0 \mathrm{mg} / \mathrm{L}$ nitrate closely indicate human activity (Dubrovsky et al. 2010).

According to quality standard of groundwater of EPA's (United States Environmental Protection Agency) maximum contaminant level (MCL) for nitrate set to $10 \mathrm{mg} / \mathrm{L}$ for protection against blue-baby syndrome. However, in other regions close to settlement site almost $70 \%$ of the wells pollution is close to threshold levels. This may cause inevitable health problems both for humans and environment.

People can be exposed to nitrate through food and water. In most cases, short-term exposure to even fairly large amounts of nitrate produces no immediate health effects on people. However, sensitive segments of the population (babies, people with health problems, and the elders) can be susceptible to problems from shortterm nitrate exposure. Infants younger than six months are especially sensitive to nitrate poisoning, which may result in serious illness or lethal ends (Chan, 2011). The illness occurs when nitrate is converted to nitrite in the infants' body. Nitrite reduces the amount of oxygen in the infants blood, causing shortness of breath and blueness of the skin (often called blue baby syndrome). The technical term for this condition is methemoglobinemia. This illness can cause the infants health to deteriorate rapidly over a period of days ( $\mathrm{Su}$ et. al., 2013).

As nitrate is the major potential ground water contaminant in study area, more is known about nitrate in ground water in Konya than other contaminants. In addition, the presence of nitrate is a sound indicator of other potential water quality problems. However, the main risky heavy metals are analyzed for having a rough picture of their contribution to groundwater wells. No serious threat were determined for $\mathrm{Cd}, \mathrm{Ni}$ and $\mathrm{Cr}$ in the site.

Table 2. Some chemical analysis of collected samples (mg/l)

\begin{tabular}{ccccccc}
\hline Well No & $\mathrm{NH}_{4}$ & $\mathrm{NO}_{2}$ & $\mathrm{NO}_{3}$ & $\mathrm{Cd}$ & $\mathrm{Ni}$ & $\mathrm{Cr}$ \\
\hline 1 & $<0.05$ & $<0.02$ & 3.4 & 0 & 2.07 & 1.79 \\
2 & $<0.05$ & $<0.02$ & 12.6 & 0 & 2.44 & 1.25 \\
3 & $<0.05$ & $<0.02$ & 11.6 & 0 & 2.11 & 1.19 \\
4 & $<0.05$ & $<0.02$ & 14.7 & 0 & 2.17 & 1.74 \\
5 & $<0.05$ & $<0.02$ & 8.7 & 0 & 2.22 & 1.68 \\
6 & $<0.05$ & $<0.02$ & 8.7 & 0 & 2.13 & 1.69. \\
7 & $<0.05$ & $<0.02$ & 10.4 & 0 & 2.14 & 1.58 \\
8 & $<0.05$ & $<0.02$ & 6.7 & 0 & 2.16 & 1.65 \\
9 & $<0.05$ & $<0.02$ & 8.6 & 0 & 1.88 & 1.64 \\
10 & $<0.05$ & $<0.02$ & 7.7 & 0 & 2.44 & 1.57 \\
11 & $<0.05$ & $<0.02$ & 11.9 & 0 & 2.27 & 1.58 \\
12 & $<0.05$ & $<0.02$ & 18.9 & 0 & 2.27 & 1.57 \\
13 & $<0.05$ & $<0.02$ & 16.9 & 0 & 2.36 & 1.59 \\
14 & $<0.05$ & $<0.02$ & 17.2 & 0 & 2.41 & 1.63 \\
15 & $<0.05$ & $<0.02$ & 10.4 & 0 & 2.18 & 1.66 \\
16 & $<0.05$ & $<0.02$ & 12.6 & 0 & 2.14 & 1.66 \\
17 & $<0.05$ & $<0.02$ & 14.5 & 0 & 2.45 & 1.87 \\
18 & $<0.05$ & $<0.02$ & 12.6 & 0 & 2.18 & 1.59 \\
19 & $<0.05$ & $<0.02$ & 14.2 & 0 & 2.19 & 1.66 \\
\hline
\end{tabular}

The $\mathrm{NO}_{3}-\mathrm{N}$ is over $3 \mathrm{mg} / \mathrm{L}$ at all sampled groundwater wells which is in congruity with Dubrovsky et all's (2010) findings that suggest $\mathrm{NO}_{3}-\mathrm{N}$ level above is related to anthropogenic pollution. The average $\mathrm{NO}_{3}-\mathrm{N}$ is $11.7 \mathrm{mg} / \mathrm{L}$ in the study site in addition to this farmers apply $280 \mathrm{~kg} \mathrm{~N} / \mathrm{ha}$ fertilizer. The total amount, groundwater and applied fertilizer is exceeding plants' $N$ requirement. Thus farmers should consider groundwater contribution prior to $\mathrm{N}$ fertilization both for environmental and economic wellbeing's. 
Farmers supply $7130 \mathrm{~mm} /$ ha water to maize via 10 to 12 irrigation. Each irrigation was applied for 12 to 15 hours that most probably cause leaching of fertilizers to groundwater. The $\mathrm{NO}_{3}-\mathrm{N}$ provided by irrigation was determined as $83 \mathrm{~kg} / \mathrm{ha}$. This amount is not taken into account by farmers which also cause leaching of excess $\mathrm{N}$ to groundwater wells. Actually the $\mathrm{N}$ requirement for maize is $250 \mathrm{~kg} / \mathrm{ha}$, but with irrigation the amount of $\mathrm{N}$ given to maize is above $400 \mathrm{~kg} / \mathrm{ha}$. This ignored $\mathrm{N}$ input via groundwater well negatively affect health and agricultural input economy in the region.

\section{CONCLUSION}

The study indicates that in many locations in the Konya Basin area namely Karapınar, Karaman and Ereğli, the groundwater nitrate and concentrations exceed the general acceptability limits, possibly due to creation of a blanket (non-point) source from regular application of fertilizers.

The groundwater well waters high nitrate content and excess fertilizer use along with irrigation for 12-15 hours at each application (a total of 10-12 irrigation is applied from May to August) in maize indicates high probability of fertilizer leaching nitrate to the groundwater aquifer. This further suggests an imbalance between plant uptake and nitrate availability in the soil.

The nitrate determined in groundwater suggested to be originated from agro-chemicals since samples were collected from fields that are far away settlement sites and industrial zones that may pollute groundwater or rains. However, more data is needed from deep drainage channels and rain for better evaluation of study findings.

The investigation also indicates that due the use of nitrate rich ground waters for irrigation is likely to increase with time, the high levels of these constituents in groundwater should be taken into consideration for recommending the fertilizer $\mathrm{N}$ for crops. Since the availability of fertilizers is limited, the use of ground waters (with elevated nitrate levels) would minimize the requirement of inorganic fertilizer applications.

\section{ACKNOWLEDGEMENT}

Authors wishes to express his profound thanks to Dr. Selim Kapur for his invaluable critics. This project is funded by TEMA Foundation, MITSUI Environmental Fund and ILEK Project RIHN, Japan.

\section{REFERENCES}

Bauder, T.A., Waskom, R. M., Davis, J. G., Sutherland, P.L. 2011. Irrigation water quality criteria. Colorado State University Extension, Fort Collins, CO, USA.

Bellitürk, K., Bağdatlı, M.C., Polat, S., Metinoğlu, M., Adnan, B.A.Ç., Kanarya, G., Karabulut, Ö. 2013. Sulama Suyu Örneklerinde Belirlenen Bazı Makro ve Mikro Elementlerin Çevre Kirliliği Açısından İki Farklı Dönemdeki Değişim Seyri: Kırklareli İli Örneği. Anadolu Doğa Bilimleri Dergisi 4(2): 82-93.
Buldur, A.D. 2010. Problems raised for meeting Konya City Drinking Water Demand. Selçuk University Ahmet Keleşoğlu Faculty of Education Journal, 30: 195-213 (in Turkish).

Chan, T.Y. 2011. Vegetable-borne nitrate and nitrite and the risk of methaemoglobinaemia. Toxicology letters, 200(1): 107-108.

Dubrovsky, N.M., Burow, K.R., Clark, G.M., Gronberg, J.M., Hamilton P.A., Hitt, K.J., Mueller, D.K., Munn, M.D., Nolan, B.T. Puckett, L.J., Rupert, M.G., Short, T.M., Spahr, N.E., Sprague, L.A., Wilber, W.G. 2010. The quality of our Nation's waters-Nutrients in the Nation's streams and groundwater, 1992-2004: U.S. Geological Survey Circular 1350.

Gao, Y., Guirui Y, Chunyan L., Pei Z. 2012. Groundwater Nitrogen Pollution and Assessment of Its Health Risks: A Case Study of a Typical Village in Rural-Urban Continuum, China. PloS one 7.4: 33982.

Guillette, L.J., Edwards. T.M. 2005. Is nitrate anecologically relevant endocrine disruptor invertebrates? Integrative and Comparative Biology, 45:19-27.

Harter, T., Lund, J. 2012. Addressing Nitrate in California's Drinking Water: Executive Summary. Addressing Nitrates in California's Drinking Water. http://groundwaternitrate.ucdavis.edu/ (Erişim tarihi: 20.12.2015)

Huang, HB., Gao Y., Cao JJ., Huang HY., Zhang, X. 2010. Nonpoint sourcepollution of nitrogen in groundwater and risk assessment in urban agricultural region of Shanghai. Journal of Soil and Water Conservation 24(3): 56-70. (In Chinese).

Jackson, B.M., Browne C.A, Butler, A.P., Peach D., Wade, A.J. 2008. Nitratetransport in chalk catchments: monitoring, modelling and policy implications. Environmental Science and Policy 11: 125-135.

Khazenzi, J.A., Osano, O., Wakhisi, J., Raburu, P. 2013. Methemoglobin in Chironomus Larvae as Potential Biomarker of Nitrate Contamination in Water. African Journal of Education, Science and Technology, 1(2): 84.

KOP. 2012. The Action Plan of State Water Works (SWW) in Konya Great Basin and Water Allocation to Wells. SWW Evaluation Report pages:61. (http://www.kop.gov.tr/pdf/KOP_\%C4\%B0DARES \%C4\%B0_DS\%C4\%B0_YAS_EYLEM_PLANI_R APORU_21_12_2012.pdf) (Erişim tarihi: 17.12.2015)

Kume, T., Akça, E., Nakano, T., Nagano, T., Kapur, S., Watanabe, T. 2010. Seasonal changes of fertilizer impacts on agricultural drainage in a salinized area in Adana, Turkey, Science of the Total Environment, 408: 3319-3326.

Kuzelka, R.D., Ennenga, W. (eds.). 2013. Nitrate contamination: exposure, consequence, and control (Vol. 30). Springer Science \& Business Media. 
Lapworth, D.J., Baran, N., Stuart, M.E., Ward, R.S. 2012. Emerging organic contaminants in groundwater: a review of sources, fate and occurrence. Environmental Pollution, 163:287-303.

Lockhart, K.M., King, A.M., Harter, T. 2013. Identifying sources of groundwater nitrate contamination in a large alluvial groundwater basin with highly diversified intensive agricultural production. Journal of Contaminant Hydrology, 151: 140-154.

Nas, B., Berktay, A. 2006. Groundwater contamination by nitrates in the city of Konya, (Turkey): A GIS perspective. Journal of Environmental Management, 79(1): 30-37.

Richards, L.A. 1954. Diagnosis and improvement of saline alkali soils. Washington DC, USA: USDA Handbook No. 60.

Rosenstock, T., Liptzin, D., Six, J., Tomich, T. 2013. Nitrogen fertilizer use in California: Assessing the data, trends and a way forward. California agriculture, 67(1): 68-79.

Shlicting, E., and Blume, H. 1966. Bodenkundliches Prakticum. Verlag Paul Parey, Hamburg-Berlin, 133pp.
Su, X., Wang, H., Zhang, Y. 2013. Health risk assessment of nitrate contamination in groundwater: A case study of an agricultural area in Northeast China. Water resources management, 27(8):3025-3034.

TSE 266. 1997. Waters-Human Consumed Waters, Turkish Standard Institution, Ankara.

TÜİK, 2012. Turkish Statistics Institute. http://www.tuik.gov.tr. (Accessed 11 January 2016).

Üstün, A., Tuşat, E., Yalvaç, S., Özkan, İ., Eren, Y., Özdemir, A., Doğanalp, S. 2015. Land subsidence in Konya Closed Basin and its spatio-temporal detection by GPS and DInSAR. Environmental Earth Sciences, 73(10): 6691-6703.

Varol, M., Gökot, B., Bekleyen, A., Şen, B. 2012. Water quality assessment and apportionment of pollution sources of Tigris River (Turkey) using multivariate statistical techniques - a case study. River research and applications, 28(9): 1428-1438.

Yilmaz, H., Demircan, V., Gül, M. 2010. Examining of Chemical Fertilizer Use Levels in Terms of Agriculture Environment Relations and Eco-nomic Losses in the Agricultural Farms: The Case of Isparta, Turkey. Bulgarian Journal of Agricultural Science, 16(2):143-157. 